\title{
界面活性剂溶液への対イオン添加によるゲル化を伴う円管内貫入流れ
}

\author{
山本 剛宏 ${ }^{* 1}$, 高御堂 直樹 ${ }^{* 2}$, 西口 隼人 ${ }^{* 1}$
}

\section{Penetrating flows with gelation due to addition of counter ions to surfactant solution in circular tube}

\author{
Takehiro YAMAMOTO*1 $^{*}$, Naoki TAKAMIDO*2 ${ }^{* 2}$ and Hayato NISHIGUCHI ${ }^{* 1}$ \\ ${ }^{* 1,}{ }^{* 2}$ Deptartment of Mechanical Engineering, Osaka University \\ 2-1 Yamadaoka, Suita-shi, Osaka 565-0871, Japan
}

Received 26 March 2014

\begin{abstract}
Penetrating flows of an aqueous solution of sodium salicylate (NaSal) through an aqueous solution of cetyltrimethylammonium bromide $(\mathrm{CTAB})$ in a circular tube were investigated experimentally. The NaSal solution flowed through the $\mathrm{CTAB}$ solution while displacing it. Network structures of wormlike micelles are formed on the interface between the solutions, and gelation occurs there. Although each test fluid has a similar Newtonian viscosity, CTAB/NaSal mixtures had strong viscoelasticity, and their viscosity greatly increased because of the gelation. Consequently, several flow patterns that do not appear in the case of Newtonian/Newtonian penetrating flows were observed. The flow patterns of the core of the penetrating flow were classified into five patterns and were mapped onto a plane of the molar concentration ratio $S$ of NaSal to $\mathrm{CTAB}$ and the penetration velocity $U$. The core exhibited a saw-tooth pattern at small $U$, which changed to a corkscrew pattern or an elastic recoil pattern as $U$ increased. Elastic recoil patterns appeared at $S=3.0$ and 5.0, where the relaxation time of a CTAB/NaSal solution is relatively long. Furthermore, a novel flow pattern in which the core flow exhibits repeated elastic recoiling was observed. In this pattern, the contracting part of the core flow exhibited alternate stretching and recoiling. Moreover, a unique phenomenon of a penetrating flow with gelation was observed. In this phenomenon, a stable tip was newly formed by the gelation after the breakup of a core. The displacement rate decreases with increasing penetration velocity and tends to be small when unstable flow patterns appear.
\end{abstract}

Key words : Penetrating flows, Gelation, CTAB, NaSal, Non-Newtonian fluids, Complex fluids

\section{1. 緒言}

溶解性・非溶解性流体の多層流孔は，石油の強化回収，管内の潤滑，多層成形やガスアシスト成形のような高 分子成形加工などの多くの工学的応用と関連して盛んに研究されてきた. 貫入流れ（penetrating flow）は流路内 の流体中に別の流体を注入し，もとの流体を置換しながら流れる多層流れの一種である.

非溶解性の二流体に関する研究では，円管内のニュートン流体へのガス浸透流れ（例えば Taylor, 1961, Bretherton, 1961, Cox, 1962, 1964, Schwartz, et al., 1986, Joseph, et al., 1997）が精力的に研究されてきた. そして, 流 路壁面に残された流体の液膜が流路内を被覆する割合は，キャピラリー数の増大とともに大きくなり，0.6に漸近 することが確かめられている，また，置換される流体の粘度が高粘度になるほど，流れは不安定になる傾向があ り，界面張力は界面の短波長の起伏を安定化するはたらきがあることが知られている，一方，高分子溶液などの 非ニュートン流体へのガス浸透流れでは，非ニュートン粘性と弾性的性質の両方が置換効率に大きく影響を及ぼ すことが報告されている. Huzyak と Koelleing（Huzyak and Koelleing, 1997）は Boger 流体へのガス浸透流れを調

No. 14-00172 [DOI: 10.1299/transjsme.14-00172], J-STAGE Advance Publication date : 5 December, 2014

${ }^{* 1}$ 正員, 大阪大学（广565-0871 大阪府吹田市山田丘 2-1）

${ }^{*}$ 大阪大学

E-mail of corresponding author: take@mech.eng.osaka-u.ac.jp 
べ，弾性効果により壁面上に形成される液膜が厚くなることを示した．Yamamoto ら（Yamamoto, et al., 2004）は 高分子水溶液への空気注入を研究し, 高分子流体の shear-thinning 粘性と法線応力差が壁面上の液膜の被覆率に影 響することを示した. そして， shear-thinning 粘性の影響はワイセンベルグ数が 1 より小さいときに現れ，ワイセ ンベルグ数が 1 より大きいときには法線応力差の影響が現れることを見いだした.

溶解性流体の貫入流れでは, 界面張力による安定化の効果は弱くなる. 円管内の貫入流れでは, Scoffoni ら （Scoffoni, et al., 2001）が垂直管内の貫入流れの実験を行い, 界面不安定が発生する臨界速度と二流体の粘度比と の関係を調べた。 さらに，二種類の不安定モード（コークスクリュー・モードと軸対称モード）が観察されるこ とを示した. Kuang ら（Kuang, et al., 2004）は, 円管内の貫入流れについて, 界面先端付近の流動パターンを PIV 計測により観測し，貫入する流体（コア部）の外側の流動パターンに対する Taylor（Taylor, 1961）の仮説とコア 内部の流動パターンに対する Petitjeans と Maxworthy（Petitjeans and Maxworthy, 1996）の仮説を実証した. 近年, 二流体界面の安定化技術の開発を目的として, 降伏応力を有する流体を潤滑流体に用いて, その中に粘塑性流体 を流す円管内貫入流れが研究されている（Huen, et al., 2007, Hormozi, et al., 2011）.

浸入流れについて多くの研究がなされているが，本研究で扱う界面におけるゲル化を伴う流動に関する研究は 少ない. 液体のゲル化は温度や $\mathrm{pH}$, 光強度の変化をトリガーとして起きる. そして, イオンの添加もゲル化のト リガーとしてのはたらきをする.イオンの添加によるゲル化を伴う貫入流れは, 流体力学的に興味深い対象であ るとともに, 細胞治療におけるタンパク質や細胞の注射可能な輸送媒体（Li, et al., 2012）のような, ゲル状物質 を用いた物質輸送への応用が考えられる.

本研究では臭化セチルトリメチルアンモニウム（cetyltrimethylammonium bromide, CTAB）水溶液中にサリチル 酸ナトリウム $(\mathrm{NaSal})$ 水溶液を注入する流れを考えた. CTAB などのひも状ミセル溶液に過剩な対イオンを添加 すると，ひも状ミセルのからみ合いが生じ，ミセルネットワーク（網目構造）の形成によるゲル化が生じる. NaSal 水溶液はしばしば, 対イオンの供給流体として用いられる。 CTAB/NaSal 水溶液は強い粘弾性を示し, 種々の特 異な特性を持つことが知られている. CTAB/NaSal 水溶液の流動挙動と流動誘起構造については多くの研究があ り, 様々な特異現象, 例えば白濁現象 (Chen and Rothstein, 2004, Hashimoto, et al., 2006, Ouchi, et al., 2006, Yamamoto, et al., 2008, Yamamoto and Taniguchi, 2012）やシアバンディング（Berret, 2006, Ezrahi, et al., 2006, Manneville, 2008, Yamamoto, et al., 2009）が報告されている. 一方, ゲル化過程における CTAB/NaSal 系の流動についてはあまり研 究がなされていない. Grumstrup と Belmonte（Grumstrup and Belmonte, 2007） は CTAB 水溶液の液面に NaSal 水 溶液の液滴を衝突した際に生じる弾性的な飛散現象に関する実験を行い, 種々の飛散パターンを観察した。

Podgorski ら（Podgorski, et al., 2007）は Hele-Shaw セル内の粘性指状体について調へ，CTAB 水溶液と NaSal 水溶 液の界面でゲル状の物質が形成され, 注入速度に応じて種々の指状体パターンが現れることを報告している.

Yamamoto ら（Yamamoto, et al., 2012）は CTAB/NaSal 系を用いて，ゲル状物質の成長と変形挙動を調べた. そこ では, NaSal 水溶液を CTAB 水溶液の流れ中に注入し, ゲル状物質の壁面への付着と成長が観察された. そして, 付着したゲル状物質の高さが主流速度と二流体の濃度比に関係することが示された。

本研究では, 円管流路中の CTAB 水溶液への NaSal 水溶液の貫入流れについて, 可視化実験を行った. そして, その流動様式を分類し，貫入速度および二流体の濃度比への依存性について調べた。

\section{2. 実験装置および方法}

\section{$2 \cdot 1$ 試料流体}

試料流体として, カチオン系界面活性剤溶液に CTAB 水溶液を, 対イオン供給流体として NaSal 水溶液を使用 した. 可視化のために, NaSal 水溶液は黒インクで着色した. CTAB 水溶液のモル濃度 $\left(C_{D}\right)$ は $0.030 \mathrm{~mol} / 1$ に固 定し, $\mathrm{NaSal}$ 水溶液のモル濃度 $\left(C_{S}\right)$ を表 1 に示寸ように変化させた. 表 1 に各流体の実験温度 $25^{\circ} \mathrm{C}$ における せん断粘度をあわせて示す，これらは，ウベローデ型粘度計で測定したものである．また，いずれの水溶液も粘 度のせん断速度依存性は示さず，ニュートン流体と考えられる. 
Table 1 Shear viscosity for test fluids at $25^{\circ} \mathrm{C}$

\begin{tabular}{c|c|c|c|c|c|c|c}
\hline \hline Test fluids & $\begin{array}{c}\text { Distilled } \\
\text { water }\end{array}$ & $\begin{array}{c}\text { CTAB } \\
0.03 \mathrm{~mol} / 1\end{array}$ & $\begin{array}{c}\text { NaSal } \\
0.03 \mathrm{~mol} / 1\end{array}$ & $\begin{array}{c}\text { NaSal } \\
0.09 \mathrm{~mol} / 1\end{array}$ & $\begin{array}{c}\text { NaSal } \\
0.15 \mathrm{~mol} / 1\end{array}$ & $\begin{array}{c}\text { NaSal } \\
0.24 \mathrm{~mol} / 1\end{array}$ & $\begin{array}{c}\text { NaSal } \\
0.30 \mathrm{~mol} / 1\end{array}$ \\
\hline $\begin{array}{c}\text { Viscosity } \\
(\mathrm{mPa} \cdot \mathrm{s})\end{array}$ & 1.06 & 1.15 & 1.06 & 1.09 & 1.15 & 1.17 & 1.17 \\
\hline
\end{tabular}

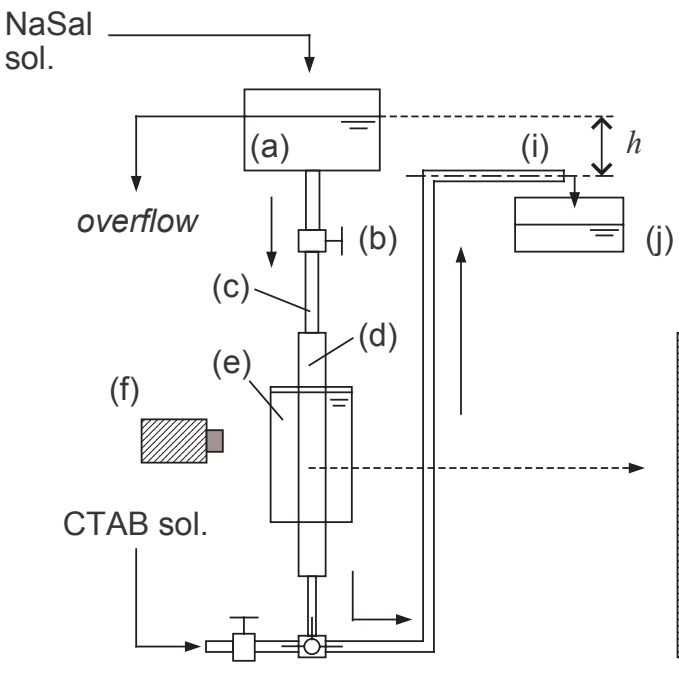

(g) (h)

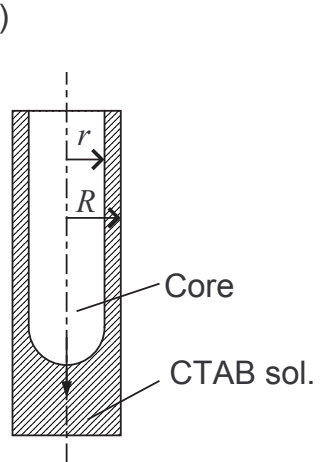

Fig.1 Schematic diagram of experimental apparatus: (a) head tank, (b) valve, (c) tube, (d) test section (circular tube), (e) viewing box, (f) digital video camera, (g) valve, (h) three-way cock, (i) exit, and (j) collector tank.

\section{$2 \cdot 2$ 実験装置}

図1に実験装置の概略図を示す。テストセクション (d) は内径 $10 \mathrm{~mm}$ ，長さ $500 \mathrm{~mm}$ のクリル製の円管で, 罒に示すように鉛直に設置され，可視化の際の円管壁の曲率の影響をなくすために，観察部は水で満たした矩形 管 (e)で覆われている.テストセクションは，はじめにCTAB水溶液で満たされており，そこにNaSal水溶液を内 径 $10 \mathrm{~mm}$ の円管(c) から注入する. NaSal水溶液の流量はヘッド差 $h$ により調整され，ヘッド差はヘッドタンク (a)からのオーバーフローにより一定に保たれている. 貫入流れの様子は，テストセクションで観測され，デジタ ルビデオカメラ（SONY製 HDR-CX590V）を用いて撮影される.

\section{$2 \cdot 3$ 実験方法}

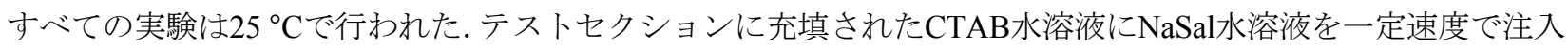
し, テストセクションの観察部（図1 (e)）において貫入流れの様子を撮影する. NaSal水溶液の注入により, CTAB 水溶液との界面でゲル化が生じる，界面でのゲル化を伴いながら，注入されたNaSal水溶液（コア部，図1参照）

は，CTAB水溶液を押し出しながら進んでいく．界面のゲル化により，インクはほとんどCTAB水溶液に拡散する ことはなかった. 本研究では, 観察結果をもとに, コア部の流動様式を分類し, それらをモル濃度比 $S=C_{S} / C_{D}$ と コア部先端速度 $U$ の平面 $(S-U$ 平面）上にマッピングして，解析を行った. コア部先端速度 $U$ は撮影画像をも

とに評価した。

さらに，式（1）で定義される置換率 $r_{d}$ を評価した。

$$
r_{d}=\frac{r^{2}}{R^{2}}
$$


ここで, $r$ は観測部の5～ 7 点の測定值を平均したコア部の平均半径, $R$ は円管内側の半径である (図1).さらに, レイノルズ数 Re を式 (2) で定義する.

$$
R e=\frac{\rho U R}{\eta_{\text {NaSal }}}
$$

ここで， $\rho$ はNaSal水溶液の密度， $\eta_{\mathrm{NaSal}}$ はNaSal水溶液の粘度である. 実際には，二流体が溶解し，またゲル化を 伴うため, レイノルズ数 Reを評価することは難しいが, 式 (2) で定義されるレイノルズ数により, 大まかな流 れ条件を把握することができると思われる. 本実験では， $U$ がおよそ $10 \sim 100 \mathrm{~mm} / \mathrm{s}$ 範囲で変化し，このとき $R e$ は50 500の值を取る. また, 通常, ゲル化が生じると, 界面付近の粘度は単体の流体のものよりも非常に高くな る（Kadoma, et al., 1997）ため, 混合溶液の粘度をもとに評価したレイノルズ数はこの值よりも数桁小さいものに なると予想される.

\section{3. 結果と考察}

\section{$3 \cdot 1$ 流動様式}

観察された流動様式のスナップショットを図2に示す、流動様式は，(a) 安定（Stable pattern, 様式S), (b) 鋸歯 (Saw-tooth pattern, 様式ST)，(c) コークスクリュー (Corkscrew pattern, 様式CS), (d) 弾性はね戻り (Elastic recoil pattern, 様式ER), (e) 安定遷移 (Unstable-to-stable pattern, 様式U-S) の5種類に分類できる.

様式Sでは, コア部は周囲のCTAB水溶液を安定的に通り抜ける。このパターンは, 貫入速度が遅い場合に見ら れた. 様式STでは, コア部と周囲流体との界面が不安定になり, 界面形状が起伏し, 鋸歯状のパターンが現れる. 様式CSでは, 起伏が生じたコア部の軸対称性が崩れ, コア部が回転し始める. そして, 界面上にコークスクリュ 一状のパターンが現れる (図3a)。コークスクリュー・パターンは, 蒸留水とグリセリンといったニュートン流体 どうしの貫入流れにおいても報告されている（Scoffoni, et al., 2001）。したがって，これは粘度の大きく異なる二 流体間の界面で生じる不安定現象であると考えられる. 様式ERでは，コア部の弾性はね戻りが生じる．はね戻り は，粘弾性流体の縮小流れにおいてしばしば見られる，コア部の縮小部が流れ方向に伸長とはね戻りを繰り返す (図3b)，この現象はゲル化した流体の弾性特性に関係すると考えられる. 様式U-Sでは, 流動初期においてはゲ ル化が十分ではなく, 界面がぼやけて不安定な挙動をする. しかし, ゲル化が進むにつれて界面が明確になり, 挙動が安定する.さらに, これらのパターンが形成されるとともに, ある条件下ではコア部の分裂が見られた. この現象については後で議論する.
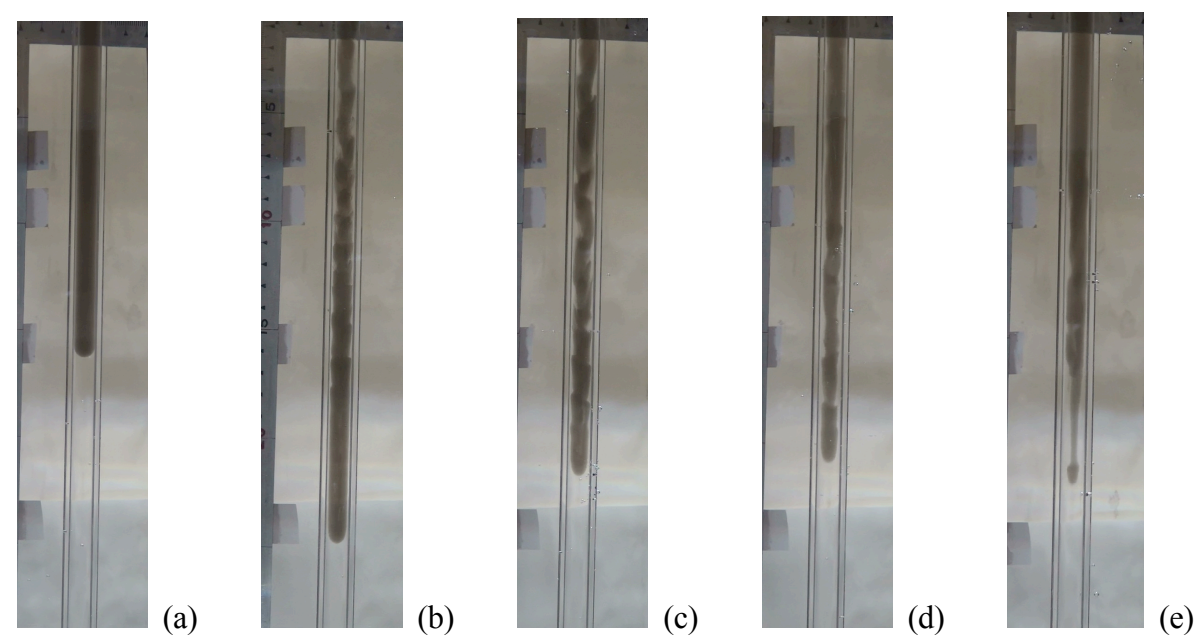

Fig. 2 Snapshots of various flow patterns in core region: (a) stable pattern (Pattern S), (b) saw-tooth pattern (Pattern ST), (c) corkscrew pattern (Pattern CS), (d) elastic recoil pattern (Pattern ER), and (e) unstable-to-stable pattern (Pattern U-S). 


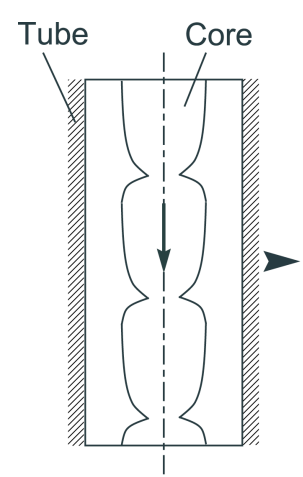

(Saw-tooth)

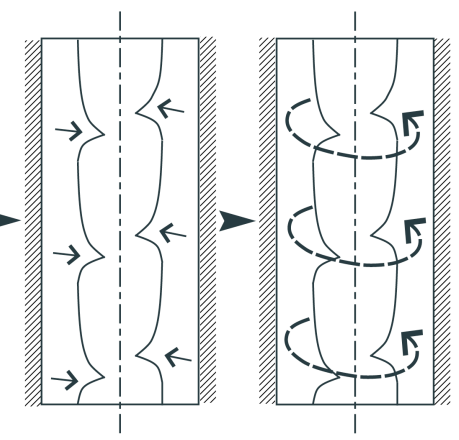

(Corkscrew) (a)

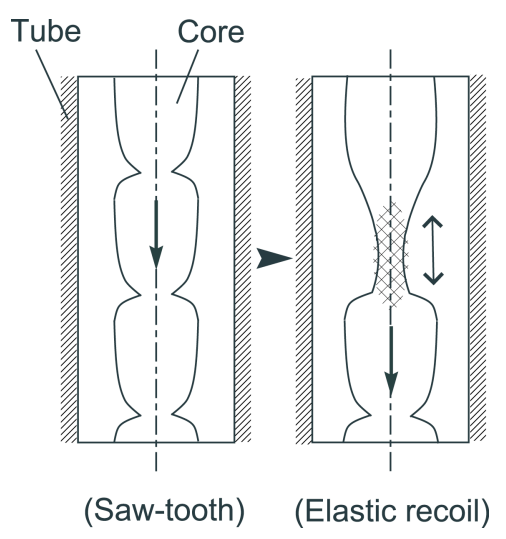

(b)

Fig. 3 Schematic diagram of transition from saw-tooth pattern to (a) corkscrew pattern and (b) elastic recoil pattern. In the elastic recoil pattern, the core repeatedly expands and contracts in the cross-hatched region.

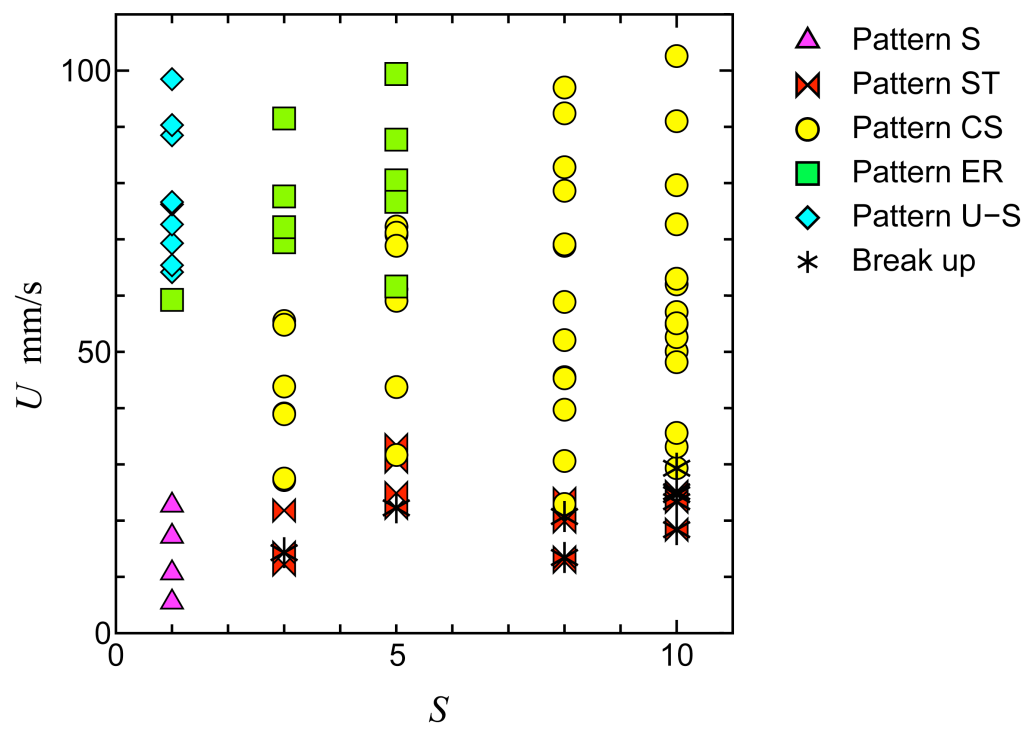

Fig. 4 Dependence of flow pattern map on molar concentration ratio $S$ and penetration velocity $U$ plane.

Table 2 Relationship between penetration velocity $U$ and representative shear rate $\Gamma$

\begin{tabular}{c|c|c|c|c|c|c}
\hline \hline $\begin{array}{c}\text { Penetration speed } \\
U(\mathrm{~mm} / \mathrm{s})\end{array}$ & 10 & 20 & 40 & 60 & 80 & 100 \\
\hline $\begin{array}{c}\text { Representative shear } \\
\text { rate } \Gamma(1 / \mathrm{s})\end{array}$ & 4.0 & 8.0 & 16 & 24 & 32 & 40 \\
\hline
\end{tabular}

ゲル化を伴う貫入流れを輸送媒体として利用する場合，コア部の流れの安定性は重要な問題であり，安定条件 を調べることは重要である. 我々は観察された流動様式を $S-U$ 平面上にマッピングし, 流動様式と $S$ および $U$ との関係を調べた．本研究では，管径を固定して実験を行っているが，管径の影響を調べることも有用である. その際には, 貫入速度ではなく, せん断速度によるデータ整理が有効と考えられる. 参考のために, Uを最大流 速とするポアズイユ流れの壁面せん断速度を代表せん断速度 $\Gamma$ として評価し，Uとの対応関係を表 2 に示寸.

図4に流動様式マップを示寸.このマップ中で，コア部の分裂が生じる条件を*印で示した. $S=1.0$ のきのコ ア部の流れ挙動は他のSのときのものとは異なる。 それは, NaSal水溶液の濃度が低く, NaSalによる対イオンの供 
給が十分ではないため, 界面のゲル化が十分に進まないからである．また，全体的な傾向として，低貫入速度で は安定流れが観察されるが, 速度の増加とともに界面が不安定になる.

$S$ が1.0より大きいときは, 低貫入速度で様式STが見られ, 速度の増加とともに様式CSに変化していく. S=8.0, 10では, 本実験の範囲において, より速い速度に対しても引き続き様式CSが現れる. しかし， $S=3.0,5.0$ のをき には, 高貫入速度域では様式ERが観察された。この違いはひも状ミセルネットワークの構造と関係すると考えら れる.

図5にCTAB/NaSal水溶液の緩和時間 $\lambda と C_{S}^{*}=C_{S}-C_{D}$ の関係を示す. 緩和時間はコーンプレート型レオメーター (Anton Paar製 Physica MCR300) を用いて応力制御条件下で測定した動的粘弾性のデータから算出したものであ る (Yamamoto and Taniguchi, 2012). CTAB/NaSal系はCTA と $\mathrm{Sal}^{+}$の1:1コンプレックスであり，したがって， $C_{S}^{*}$ は溶液中の自由な $\mathrm{Sal}^{-}$の濃度を表す. Shikataら（Shikata, et al., 1987, 1988）は系の緩和時間が $C_{S}{ }^{*}$ と関係があること を報告している. 図5に示すように, $S=8.0,10$ では緩和時間は $C_{S}{ }^{*}$ の増加とともに短くなるが, $S=3.0,5.0 て ゙ は C_{S}{ }^{*}$ の増加とともに緩和時間が長くなり, 他の条件に比べて比較的大きなネットワーク構造が形成され, 粘弾性が強 くなると考えられる.コア部表面付近の流体は，CTAB $\mathrm{NaSal}$ の完全な混合溶液にはなっていないと考えられる が, 表面付近のネットワーク構造はCTAB/NaSal混合溶液と同様の $S$ 依存性を示すと予想される. したがって, $S=$ 3.0, 5.0 の水溶液では粘弾性が強く, そのために, 様式ERは $S=3.0,5.0$ の高貫入速度域で顕著に現れたと考えられ る.

また，コア部先端の特異な挙動が観察された. 図4に示すように，Uが小さく，Sが大きい場合に，コア部が流 動中に分裂することがある. その分裂後に特異な挙動が現れる. 図6に $S=8.0, U=20.7 \mathrm{~mm} / \mathrm{s}$ ときの分裂前後の コア部の様子を示寸，くびれが生じた部分で分裂が始まる（図6b)，そして，分裂後に生じた先端部の界面でゲル 化が起こり (図6c), 安定した界面が形成される（図6d）、コア部の分裂が生じるが，対イオンの供給が十分であ れば，分裂によって現れた界面でゲル化が進むために，後方のコア部先端に新たな安定な界面が形成される．こ の現象はゲル化を伴う貫入流れに特有の現象である.

\section{$3 \cdot 2$ 置換率}

次に置換率 $r_{d}$ と貫入速度 $U$ との関係を調べる. 図7に種々のモル濃度比 $S$ につい $r_{d}$ とU の関係を示す. 図 中の誤差棒は $r_{d}$ の最大值と最小值を示している. 図には流動様式もあわせて示した. 置換率は明確な $S$ 依存性 を示さないが，流動様式との関連性が見られる．全般的に浸入速度の増大とともに置換率は低下寸る傾向が見ら れる．また，コア部の流れが比較的安定な低貫入速度では $r_{d}$ は大きい，しかし，高貫入速度ではコークスクリ ユー・パターンあるいは弾性はね戻りパターンが現れるため, $r_{d}$ の変動が大きくなり, 置換率は低下寸る. した がって, コア部の流れが安定した状態では置換率が大きく, 不安定流れになると置換率が小さくなると言える.

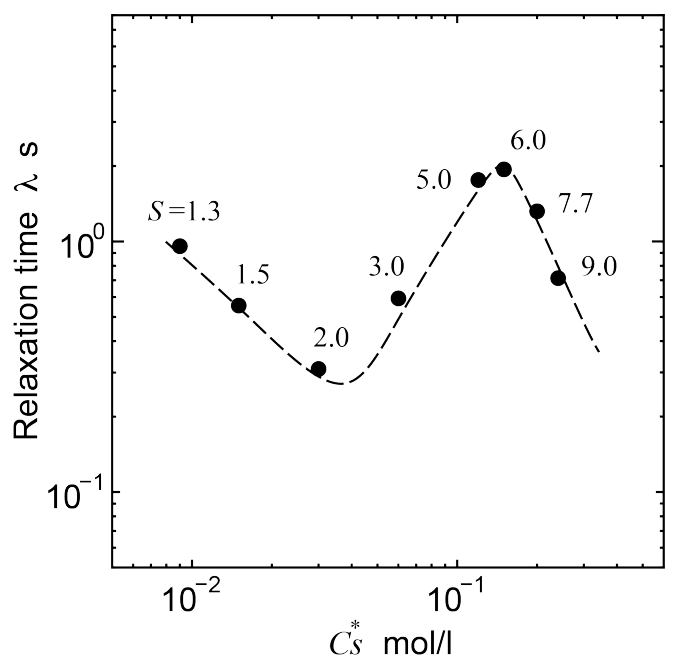

Fig. 5 Relaxation time for $\mathrm{CTAB} / \mathrm{NaSal}$ solutions as function of concentration of free $\mathrm{Sal}^{-}$ions $C_{S}{ }^{*}$ at $25^{\circ} \mathrm{C}$. 

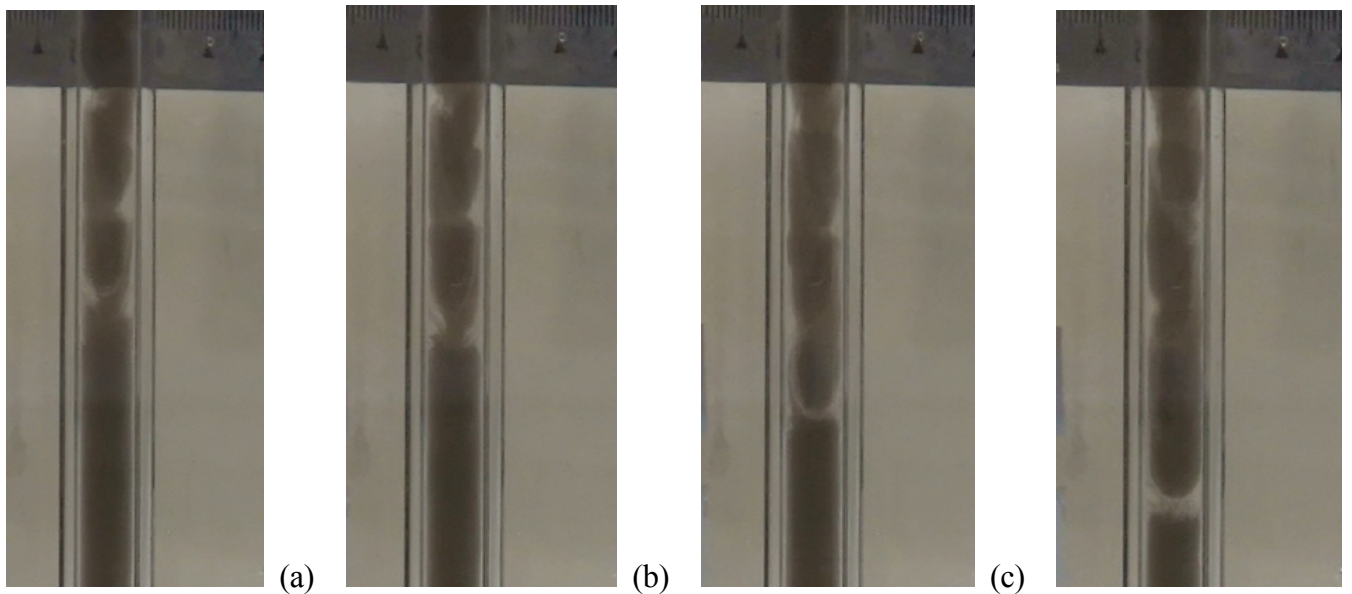

(d)

Fig. 6 Snapshots of breakup behavior of core flow: $S=8.0$ and $U=20.7 \mathrm{~mm} / \mathrm{s}$. Time advances from left to right.

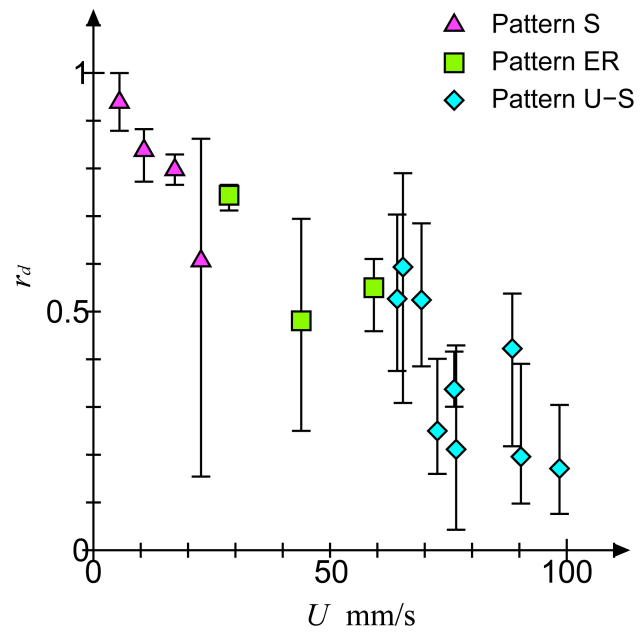

(a)

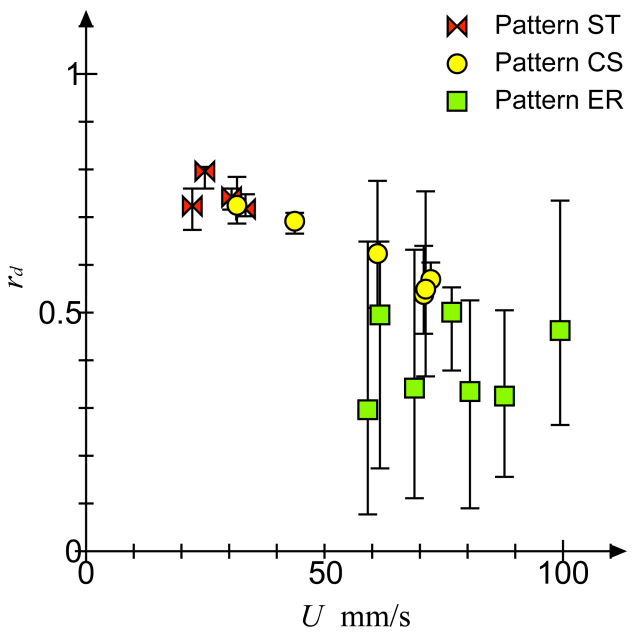

(c)

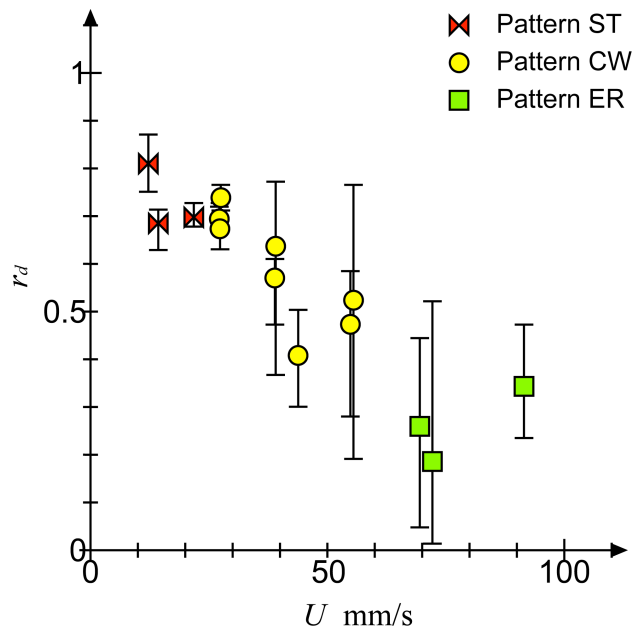

(b)

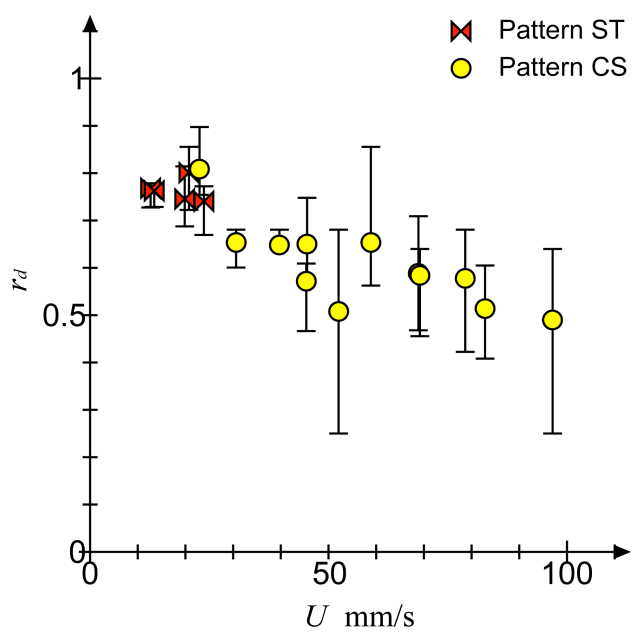

(d)

Fig. 7 Displacement rate $r_{d}$ as function of penetration velocity $U$ for $S=$ (a) 1.0, (b) 3.0, (c) 5.0, (d) 8.0, and (e) 10 . 


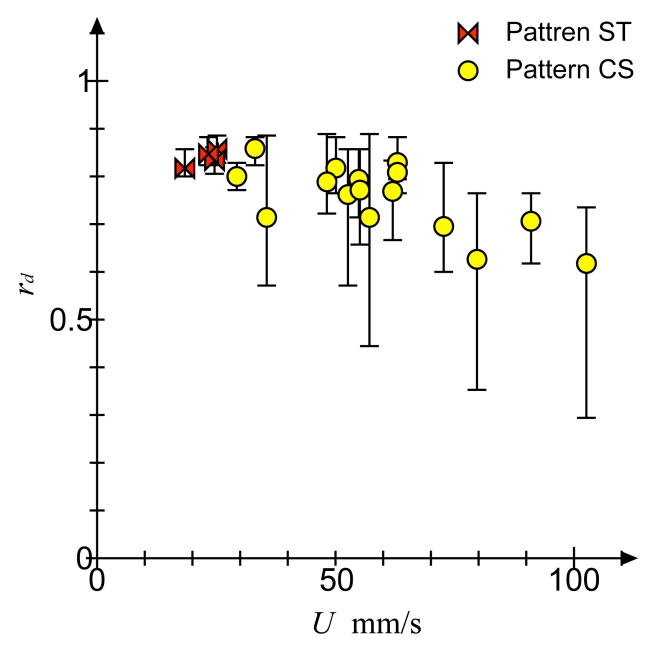

(e)

Fig. 7 (continued)

\section{4. 結 言}

本研究では，円管流路中のCTAB水溶液へのNaSal水溶液の貫入流れについて調べた。二流体の界面でミセルネ ットワーク構造の形成によるゲル化が生じながら，コア部の流体は周囲流体を押し出して流れる。両流体はほぼ 同じニュートン粘性を示すが，それらの混合液は強い粘弾性を示し，その粘度はゲル化のために非常に大きくな る.したがって, ニュートン流体どうしの貫入流れでは見られない流動様式が観察された.

我々は貫入流れのコア部の流動様式を 5 種類のパターンに分類し, モル濃度比 $S$ と貫入速度 $U$ の平面上にマ ッピングした. 流動様式は $S$ と $U$ に依存し，Uが小さい時には鋸歯パターンを示し，Uの増大とともにコークス クリュー・パターンあるいは弾性は衩戻りパターンに変化する。弾性は祀戻りパターンは, CTAB/NaSal 水溶液 の粘弾性特性が強くなっていると考えられる $S=3.0,5.0$ の条件において現れた. さらに, 我々はコア部の流れが 弾性はね戻り現象を繰り返す新しい流動様式を見いだした．このパターンでは，コア部のくびれた部分が伸長と は㸚戻りを繰り返す。また，コア部の破断が生じた際に新たに安定した先端部がゲル化により形成される，ゲル 化を伴う貫入流れ特有の現象も見られた．さらに，置換率 $r_{d}$ の解析では，貫入速度を上げると $r_{d}$ が低下し，コ ア部の流れが不安定挙動を示寸Uが大きい領域では, 置換率の変動が大きくなることが分かった．また，ゲル化 の進行による流動様式の変化のメカニズムの解明のためには, 今後, ゲル化速度を評価し, 流動様式との関係を 調べる必要がある. また, 界面の安定性については, 界面レオロジーとの関係も強いと予想され, 表面レオロジ 一の評価も今後の課題である.

\section{References}

Berret, J.-F., Rheology of wormlike micelles: Equilibrium properties and shear banding transition, Molecular Gels edited by Weiss, R. G. and Terech, P. (2006), pp. 667-720. Springer.

Bretherton, F.P., The Motion of long bubbles in tubes, Journal of Fluid Mechanics, Vol.10 (1961), pp.166-188.

Chen, S. and Rothstein, J. P., Flow of a wormlike micelle solution past a falling sphere, Journal of Non-Newtonian Fluid Mechanics, Vol.116, Nos.2-3 (2004), pp.205-234.

Cox, B.G., On driving a viscous fluid out of a tube, Journal of Fluid Mechanics, Vol.14 (1962), pp.81-96.

Cox, B.G., An experimental investigation of the streamlines in viscous fluid expelled from a tube, Journal of Fluid Mechanics, Vol.20 (1964), pp.193-200.

Ezrahi, S., Tuval, E. and Aserin, A., Properties, main applications and perspectives of worm micelles, Advances in Colloid and Interface Science, Vols.128-130 (2006), pp.77-102. 
Grumstrup, T. and Belmonte, A., Elastic splash of two Newtonian liquids, Physics of Fluids, Vol.19, No.9 (2007), p.091109-1.

Hashimoto, T., Kido, K., Kaki, S., Yamamoto, T. and Mori, N., Effects of surfactant and salt concentrations on capillary flow and its entry flow for wormlike micelle solutions, Rheologica Acta, Vol.45, No.6 (2006), pp.841-852.

Hormozi, S., Martinez, D.M. and Frigaard, I.A., Stable core-annular flows of viscoelastic fluids using the visco-plastic lubrication technique, Journal of Non-Newtonian Fluid Mechanics, Vol.166, Nos.23-24 (2011), pp.1356-1368.

Huen, C.K., Frigaard, I.A. and Martinez, D.M., Experimental studies of multi-layer flows using a visco-plastic lubricant, Journal of Non-Newtonian Fluid Mechanics, Vol.142, Nos.1-3 (2007), pp.150-161.

Huzyak, P.C. and Koelling K.W., The penetration of a long bubble through a viscoelastic fluid in a tube, Journal of Non-Newtonian Fluid Mechanics, Vol.71, Nos.1-2 (1997), pp.73-88.

Joseph, D.D., Bai, R., Chen, K.P. and Renardy, Y.Y., Core-annular flows, Annual Review of Fluid Mechanics, Vol.29 (1997), pp.65-90.

Kadoma, I. A., Ylitalo, C. and van Egmond, J. W., Structural transitions in wormlike micelles, Rheologica Acta, Vol.36, No.1 (1997), pp.1-12.

Kuan, J., Petitjeans, P. and Maxworthy, T., Velocity fields and streamline patterns of miscible displacement in cylindrical tube, Experiments in Fluids, Vol.37, No.2 (2004), pp.301-308.

Li, Y., Rodrigues, J. and Tomás, H., Injectable and biodegradable hydrogels: gelation, biodegradation and biomedical applications, Chemical Society Reviews, Vol. 41, No.6 (2012), pp.2193-2221.

Manneville, S., Recent experimental probes of shear banding, Rheologica Acta, Vol.47, No.3 (2008), pp.301-318.

Ouchi, M., Takahashi, T. and Shirakashi, M., Shear-induced structure change and flow-instability in start-up Couette flow of aqueous wormlike micelle solution, Journal of Rheology, Vol.50, No.3 (2006), pp.341-352.

Petitjeans, P. and Maxworthy T., Miscible displacements in a capillary tube. Part 1. Experiments, Journal of Fluid Mechanics, Vol.326 (1996), pp.37-56.

Podgorski, T., Sostarecz, M.C., Zorman, S. and Belmonte, A., Fingering instabilities of a reactive micellar interface, Physical Review E, Vol.76, Vol.1 (2007), pp.016202-1-016202-6.

Scoffoni, J., Lajeunesse, E. and Homsy, M. G. Interface instabilities during displacements of two miscible fluids in a vertical pipe, Physics of Fluids, Vol.13, No.3 (2001), pp.553-556.

Shikata, T., Hirata, H. and Kotaka, T., Micelle formation of detergent molecules in aqueous media: Viscoelastic properties of aqueous cetyltrimethylammonium bromide solutions, Langmuir, Vol.3, No.6 (1987), pp.1081-1086.

Shikata, T., Hirata, H. and Kotaka, T., Micelle formation of detergent molecules in aqueous media. 2. Role of free salicylate ions on viscoelastic properties of aqueous cetyltrimethylammonium bromide-sodium salicylate solutions, Langmuir, Vol.4, No.2 (1988), pp.354-359.

Taylor, G.I., Deposition of a viscous fluid on the wall of a tube, Journal of Fluid Mechanics, Vol.10 (1961), pp.161-165.

Yamamoto, T. Suga, T., Nakamura, K. and Mori, N., The gas penetration through viscoelastic fluids with shear-thinning viscosity in a tube, Transactions of ASME Journal of Fluid Engineering, Vol.126, No.2 (2004), pp.148-152.

Yamamoto, T., Hashimoto, T. and Yamashita, A., Flow analysis for wormlike micellar solutions in an axisymmetric capillary channel, Rheologica Acta, Vol.47, No.9 (2008), pp.963-976.

Yamamoto, T., Sawa, K. and Mori, K., Velocity measurements for shear flows of CTAB/NaSal aqueous solutions between parallel plates, Journal of Rheology, Vol.53, No.6 (2009), pp.1347-1362.

Yamamoto, T., Suzuki, J. and Taniguchi, K., Adhesion and growth phenomena of gel-like materials induced by injection of NaSal into flow of aqueous solution of CTAB, Nihon Reoroji Gakkaishi, Vol.40, No.2 (2012), pp.55-60.

Yamamoto, T. and Taniguchi, K., Emergence of white turbid region in startup flow of CTAB/NaSal aqueous solutions between parallel plates, Journal of Rheology, Vol.56, No.2 (2012), pp.245-258. 